\title{
Pengembangan Media Scrapbook Berbasis Picture And Picture Berorientasi Wawasan Kebangsaan
}

\author{
Didit Yulian Kasdriyanto $^{1}$, Ludfi Arya Wardana ${ }^{\circledR} \bowtie$ \\ Pendidikan Guru Sekolah Dasar, Universitas Panca Marga Probolinggo, Indonesia ${ }^{(1,2)}$ \\ DOI: $10.31004 /$ obsesi.v6i1.1255
}

\begin{abstract}
Abstrak
Permasalahan pembelajaran anak usia dini umur 6-8 tahun ditemukan yaitu, hasil belajar siswa yang belum optimal dan kurangnya minat belajar siswa. Tujuan penelitian ini adalah menghasilkan media scrapbook berbasis picture and picture berorientasi wawasan kebangsaan yang valid, praktis dan efektif pada anak umur 6-8 tahun di sekolah dasar. Penelitian ini menggunakan model pengembangan Borg \& Gall. Pengembangan yang dilakukan diawali dengan studi pendahuluan, dilanjutkan dengan perencanaan, desain produk, validasi produk, uji coba produk dan produk akhir. Hasil validasi ahli materi valid tanpa revisi dan hasil validasi ahli media mencapai valid tanpa revisi. Uji coba terbatas dilakukan kepada guru dan siswa SD Namira School Probolinggo. Hasil rata-rata angket kepraktisan guru valid tanpa revisi. Hasil evaluasi belajar siswa menunjukkan 20 siswa telah tuntas belajar. Berdasarkan hasil di atas, media ini telah valid, praktis dan efektif sehingga media ini dapat meningkatkan proses dan hasil belajar serta menanamkan wawasan kebangsaan sejak usia dini.
\end{abstract}

Kata Kunci: scrapbook berbasis picture and picture; wawasan kebangsaan; anak usia dini.

\begin{abstract}
Early childhood learning problems aged 6-8 years were found, namely, student learning outcomes were not optimal and students' lack of interest in learning. The purpose of this research is to produce a picture and picture-oriented scrapbook media with national insight that is valid, practical and effective for children aged 6-8 years in elementary school. This study uses the Borg \& Gall development model. The development carried out begins with a preliminary study, followed by planning, product design, product validation, product testing and the final product. The results of the validation of the material experts are valid without revision and the results of the validation of the media experts are valid without revision. Limited trials were conducted on teachers and students of SD Namira School Probolinggo. The average result of the teacher practicality questionnaire is valid without revision. The results of the student learning evaluation showed that 20 students had finished learning. Based on the above results, this media has been valid, practical and effective so that this media can improve learning processes and outcomes and instill national insight from an early age.
\end{abstract}

Keywords: scrapbook based picture and picture; national insight; early childhood

Copyright (c) 2021 Didit Yulian Kasdriyanto, Ludfi Arya Wardana

$\square$ Corresponding author:

Email Address : ludfiaryawardana@upm.ac.id (Kota Probolinggo, Jawa Timur)

Received 9 April 2021, Accepted 26 April 2021, Published 27 April 2021 


\section{PENDAHULUAN}

Pendidikan penting diberikan kepada seluruh anak sekolah dasar anak umur 6-8 tahun kelas II SD untuk mengembangkan daya pemahaman dan pola pikir kritisnya. Pendidikan dapat menjadi penentu terciptanya generasi penerus bangsa yang berkualitas. Menurut Abtahi, (2012) pembelajaran tematik di anak umur 6-8 tahun SD yang memfokuskan pada pembelajaran bermakna dan utuh sehingga dibutuhkan media perantara yang mudah dipahami siswa.

Selain itu, pada satuan pendidikan dasar terutama umur 6-8 tahun harus dikenalkan pembelajaran bermakna dengan menggunakan media yang menarik. Tujuannya untuk menanamkan pembelajaran kontekstual sehingga mementuk karakter yang baik sejak usia dini Atkins, R., Turner, A. J., Chandola, T., \& Sutton, (2020). Pembelajaran pada anak umur 68 tahun ini memiliki aspek utama sebagai pendidikan nilai dan moral pada akhirnya akan bermuara pada watak atau karakter peserta didik sesuai dengan dan merujuk pada nilai-nilai dan moral Pancasila. Rulyansah, A., Wardana, L. A., \& Sari, (2018) nilai dan wawasan kebangsaan dapat dikembangkan dalam diri siswa.

Pada kenyataannya, pembelajaran umur 6-8 tahun yang sedang berlangsung saat ini masih sulit untuk diwujudkan dan belum sesuai dengan harapan karena belum ada media yang memberikan wawasan kebangsaan pada usia dini. Permasalahan pembelajaran di anak umur 6-8 tahun juga ditemukan salah satunya pada siswa umur 6-8 tahun SD Namira School. Hasil belajar siswa yang belum optimal, dan kurangnya minat belajar siswa pada pembelajaran membuat peneliti untuk memberikan solusi.

Pembelajaran yang dilakukan pada tema hidup rukun umur 6-8 tahun SD Namira School Probolinggo bahwa guru kesulitan membuat siswa aktif dalam pembelajaran. Biasanya pada pembelajaransiswa cenderung pasif, hanya mendengarkan penjelasan guru. Suasana pembelajaran yang cenderung pasif membuat siswa merasa bosan dan jenuh saat menerima pelajaran, dampaknya materi pelajaran yang telah dijelaskan oleh guru tidak dapat dipahami secara maksimal.

Permasalahan pembelajaran yang belum optimal serta kurangnya minat belajar siswa pada pembelajaran. Dengan memperhatikan berbagai alternatif pemecahan masalah tersebut, maka peneliti menetapkan suatu alternatif pemecahan masalah yaitu dengan media scrapbook. Tapi pemecahan masalah dengan media scrapbook ini sedikit berbeda yaitu dengan mengembangkan media yang inovatif. Dengan media yang inovatif, siswa dapat belajar dengan aktif dan terlibat dalam penggunaan media yang menarik dan memiliki wawasan kebangsaan sesuai dengan perkembangannya. Media pembelajaran inovatif untuk mengatasi masalah tersebut adalah media scrapbook. Yaitu mengembangkan media scrapbook berbasis picture and picture berorientasi wawasan kebangsaan yang mempunyai kelebihan meningkatkan minat dan hasil belajar siswa (Fauziyah et al., 2020). Menurut (Pertiwi, 2019) penggunaan media scrapbook pada anak usia dini dapat mempengaruhi perkembangan kognitif.

Hasil penelitian terdahulu (Rulyansah, A., Wardana, L. A., \& Sari, 2018) mengemukakan bahwa wawasan kebangsaan dapat ditanamkan dalam anak sejak awal untuk memperkuat jiwa nasiolisme dalam perkembangannya. Selain itu,(Rulyansah and Wardana, 2020) mengemukakan bahwa perangkat pembelajaran termasuk di dalamnya media pembelajaran berupa scrapbook dapat meningkatkan minat dan motivasi belajar siswa kelas rendah sehingga pembelajaran dapat bermakna. Hasil penelitian dari (Wardana and Hasanah, 2019)bahwa model pembelajaran dalam pengembangan pengelolaan kelas yang dapat meningkatkan kenyamanan belajaran siswa termasuk model pembelajaran picture and picture. Pada penelitian ini mengkombinasikan variabel media scrapbook dan metode picture and picture serta wawasan kebangsaan yang sekarang masih jarang dikembangkan di anak usia dini.

Berdasarkan paparan di atas, tujuan penelitan pengembangan ini adalah untuk menghasilkan produk berupa media scrapbook berbasis picture and picture berorientasi wawasan kebangsaan yang valid, praktis dan efektif pada kelas II (umur 6-8 tahun) di sekolah 
dasar. Kebaruan dalam produk ini yaitu media yang dapat meningkatkan proses dan hasil belajar serta menumbuhkan wawasan kebangsaan pada anak sejak usia dini. Kontribusi dalam keilmuan yaitu mengkombinasikan media scrapbook dan metode picture and picture serta menambahkan variabel wawasan kebangsaan.

\section{METODOLOGI}

Metode research and develepmont yang digunakan dalam mengembangan produk desain media scrapbook berbasis picture and picture berorientasi wawasan kebangsaan pengembangan model Borg \& Gall. Riset pengembangan ini memakai model tipe pengembangan (Borg and Gall, 1983) yang sudah dimodifikasi jadi:( 1) pengumpulan data, (2) perencanaan,(3) pengembangan produk,(4) uji expert,(5) uji lapangan,(6) produk akhir.

Prosedur research and develepmont terdiri dari( 1) riset pendahuluan,( 2) perencanaan, (3) pengembangan produk, (4) uji expert, (5) perbaikan hasil validasi, (6) uji lapangan, (7) penyempurnaan produk akhir, serta( 8 ) produk akhir. Desain uji coba pada pengembangan ini dicoba lewat 2 sesi, ialah sesi validasi ahli serta uji coba lapangan. Validasi yang dicoba oleh 2 validator ahli, ialah teknologi pendidikan serta materi. Sehabis dicoba validasi, setelah itu hendak dicoba perbaikan. Hasil perbaikan tersebut setelah itu diuji coba lapangan pada guru serta siswa Anak umur 6-8 tahun SD Namira School Probolinggo.

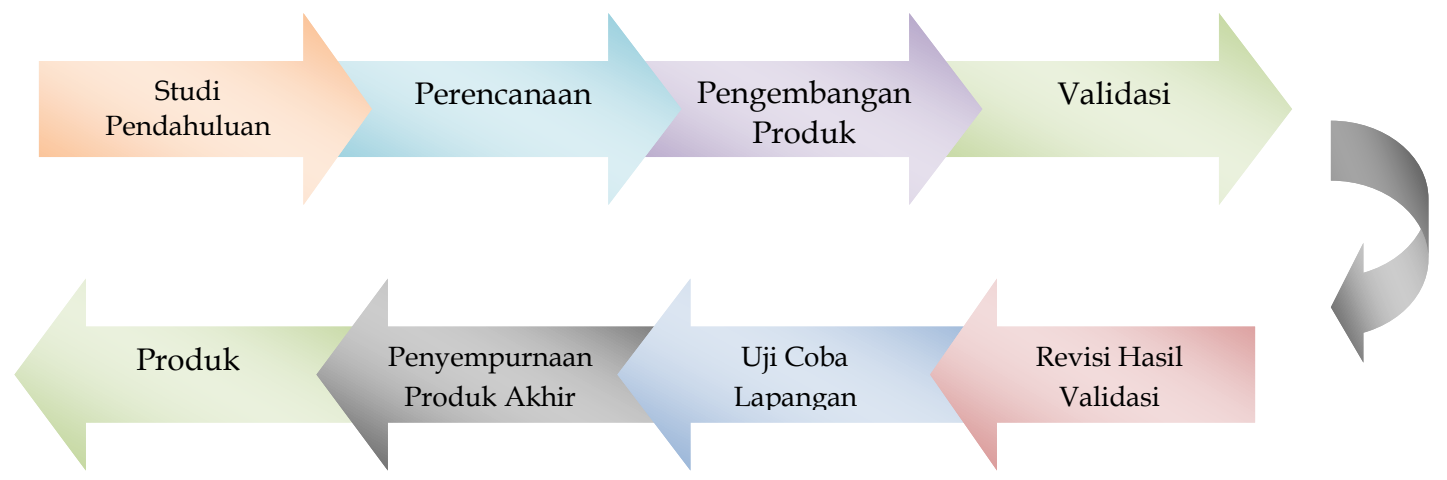

Gambar 1 Diagram Alir Borg \& Gall pada media scrapbook.

Langkah dini dalam riset ini merupakan melaksanakan riset pendahuluan. Kegiatankegiatan yang dicoba ialah: a) analisis partisipan, b) analisis teknologi, c) analisis media, dan d) identifikasi permasalahan. Kegiatan- kegiatan ini dicoba buat pengumpulan data dini selaku modal dini melakukan riset. Sehabis riset pendahuluan, dilanjutkan penataan rencana penerapan riset.

Perencanaan merupakan mengkaji informasi yang diperoleh dari riset pendahuluan, melaksanakan analisis pengembangan media scrapbook berbasis picture and picture berorientasi pengetahuan kebangsaan yang hendak jadi pemecahan penjadwalan, kerja regu, spesifikasi media, struktur isi serta kontrol konfigurasi. Aktivitas perencaan ini dicoba supaya riset jadi sistematis serta prosedural. Pengembangan produk, peneliti mulai menyusun produk yang hendak diteliti serta dibesarkan meliputi menyusun kerangka kerja tiap- tiap anggota regu, membuat spesifikasi panduan, membuat serta desain, melaksanakan pembahasan langkah pemilihan serta langkah media pendidikan.

Uji coba kelayakan produk yang dilakukan meliputi: (1) uji validasi dari ahli teknologi pembelajaran dan ahli materi dan (2) uji coba lapangan. Validasi ahli dilakukan dengan menggunakan instrumen validasi yang telah disusun. Hal ini dilakukan untuk mengetahui kesesuaian produk yang telah disusun dan dikembangkan secara teoritik. Subyek coba pengembangan produk riset ini merupakan ahli teknologi pendidikan, ahli materi, guru dan siswa anak umur 6-8 tahun SD Namira School Probolinggo. Tipe informasi yang diperoleh dalam riset ini berbentuk informasi kuantitatif serta kualitatif. Informasi kuantitatif ialah jumlah nilai angket validasi uji modul ataupun isi serta pakar bahasa, hasil angket guru serta 
angket siswa berikutnya dijabarkan secara kualitatif. Informasi kualitatif diperoleh dari penjelasan anjuran revisi validator teknologi pendidikan ataupun isi, asumsi guru serta siswa anak umur 6-8 tahun.

Analisis data yang digunakan dalam penelitian dan pengembangan ini yaitu analisis deskriptif kualitatif dan deskriptif kuantitatif. Analisis data kualitatif digunakan untuk mengolah data dari ahli dan pengguna. Sedangkan analisis data kuantitatif dilakukan pada skor angket dan tes. Analisis data ini dimaksudkan untuk mengetahui tingkat ketercapaian berdasarkan kriteria yang telah ditentukan. Pengumpul informasi pada riset ini dibagi jadi 2, awal perlengkapan pengumpulan informasi pada pengumpulan data pendahuluan serta pengumpul informasi pada riset pengembangan (Hobri, 2010). Buat instrumen pengumpul informasi pendahuluan berbentuk angket guru serta siswa anak umur 6-8 tahun dan pedoman wawancara guru.

\section{HASIL DAN PEMBAHASAN}

Berdasarkan hasil survey di anak umur 6-8 tahun dalam pembelajaran pada tema hidup rukun bahwa guru kesulitan membuat siswa aktif dalam pembelajaran. Biasanya pada pembelajaran siswa cenderung pasif, hanya mendengarkan penjelasan guru. Suasana pembelajaran yang cenderung pasif membuat siswa merasa bosan dan jenuh saat menerima pelajaran, dampaknya materi pelajaran yang telah dijelaskan oleh guru tidak dapat dipahami secara maksimal (Wardana, L.A. ; Alawiyah, 2021). Pada pemanfaatan media pembelajaran guru harus memanfaatkan lingkungan sekitar sebagai potensi sumber belajar terdekat siswa (Halim, Abdul; Wardana, 2017). Hadirnya media scrapbook dapat menjadi perantara menyampaikan materi sesuai lingkungan terdekat siswa.
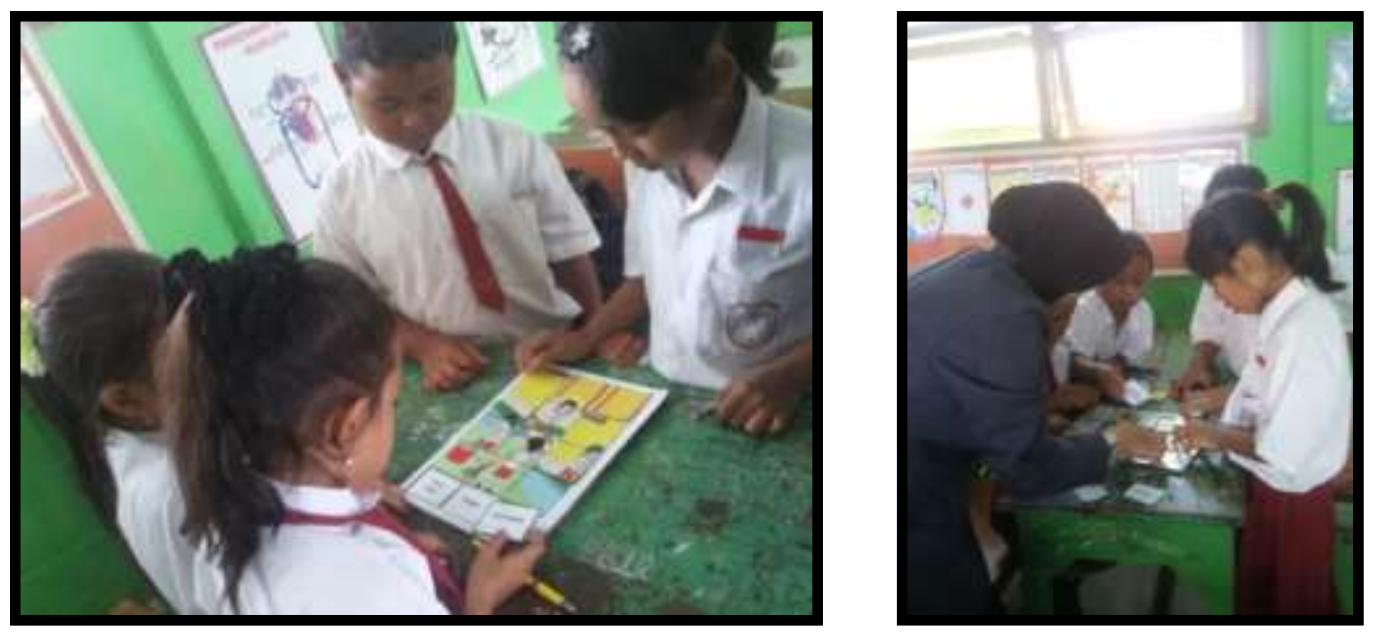

\section{Gambar 2 Penggunaan media scrapbook dengan bimbingan guru}

Berdasarkan Gambar 2 tentang penggunaan media scrapbook dilakukan dengan bimbingan guru. Hal tersebut berpengaruh pada hasil belajar yang agar optimal, dan meningkatkan minat belajar siswa pada pembelajaran. Berikut ini penggunaan media dan hasil tingkat kevalidan materi dan media pembelajaran.

Berdasarkan tabel 1 tingkat kevalidan materi media scrapbook berbasis picture and picture berorientasi wawasan kebangsaan 94\%. Kebenaran materi, kedalaman materi, pentingnya materi, kemenarikan materi, kemudahan memahami materi,penggunaan bahasa, kejelasan konsep yang diberikan dan tingkat kesulitan soal sudah sangat baik, namun harus sedikit diperbaiki pada jumlah media. Yaitu memperbanyak media scrapbook berbasis picture and picture berorientasi wawasan kebangsaan. Berikut hasil angket kevalidan media pembelajaran. 
Pengembangan Media Scrapbook Berbasis Picture And Picture Berorientasi Wawasan Kebangsaan DOI: 10.31004/obsesi.v6i1.1255

Tabel 1 Hasil Validasi Ahli Materi Pembelajaran Anak Umur 6-8 Tahun

\begin{tabular}{clc}
\hline No & \multicolumn{1}{c}{ Indikator } & Hasil Penilaian \\
\hline 1 & Kebenaran materi & 4 \\
2 & Kedalaman materi & 4 \\
3 & Pentingnya materi & 4 \\
4 & Kemenarikan materi & 3 \\
5 & Materi mudah dipahami & 3 \\
6 & Penggunaan bahasa yang tepat dan konsisten & 4 \\
7 & Konsep yang diberikan dapat dilogika dengan jelas & 4 \\
8 & Kesesuaian dengan situasi siswa & 4 \\
9 & Tingkat kesulitan soal yang sesuai dengan karakteristik siswa & 4 \\
\hline & Rata-rata persentase & $94 \%$ \\
\hline
\end{tabular}

Sumber: Data Hasil Validasi

Tabel 2 Hasil Validasi Ahli Media Pembelajaran

\begin{tabular}{clc}
\hline No & \multicolumn{1}{c}{ Indikator } & Hasil Penilaian \\
\hline 1 & Kejelasan petunjuk penggunaan & 4 \\
2 & Kemudahan menggunakan media pembelajaran & 4 \\
3 & Kesesuaian jenis dan ukuran huruf dengan karakteristik siswa & 4 \\
4 & Kesesuaian gambar dengan karakteristik siswa dan materi & 3 \\
5 & Kesesuaian desain media pembelajaran dengan karakteristik siswa & 3 \\
6 & Membantu pemahaman materi & 4 \\
7 & Membangkitkan motivasi siswa belajar & 4 \\
8 & Menarik minat belajar siswa & 4 \\
\hline Rata-rata dalam presentase & $93 \%$ \\
\hline
\end{tabular}

Sumber: Data Hasil Validasi

Berdasarkan tabel 2 hasil kevalidan media mencapai 93\%, yang berarti valid dan tidak perlu revisi. dilakukan pengambilan rata-rata untuk mendapatkan hasil tingkat kevalidan media scrapbook berbasis picture and picture berorientasi wawasan kebangsaan (Vb). Hasil tingkat kevalidan media scrapbook berbasis picture and picture berorientasi wawasan kebangsaan $(\mathrm{Vb})$ mencapai persentase $93 \%$. Berikut ini hasil analisis tingkat kevalidan materi dan media pembelajaran.

Tabel 3. Hasil Analisis Tingkat Kevalidan Materi dan Media Pembelajaran

\begin{tabular}{|c|c|c|}
\hline Validator & Hasil & Komentar dan Saran \\
\hline Materi & $\begin{array}{r}V m=94 \%, \text { valid dan } \\
\text { tidak perlu revisi }\end{array}$ & $\begin{array}{l}\text { - Hanya menggunakan } 1 \text { media saja } \\
\text { Media diperbanyak sesuai dengan jumlah } \\
\text { kelompok siswa yang dibentuk. }\end{array}$ \\
\hline Media & $\begin{aligned} V d= & 93 \%, \text { valid dan } \\
& \text { tidak perlu revisi }\end{aligned}$ & $\begin{array}{l}\text { Warna tulisan gambar kurang menarik, } \\
\text { sebaiknya kartu soal dibuat lebih berwarna } \\
\text { biar lebih menarik. } \\
\text { - Warna tulisan pada judul paling atas kurang } \\
\text { sesuai dengan baground, sebaiknya warna } \\
\text { tulisan disesuaikan dengan baground cover }\end{array}$ \\
\hline
\end{tabular}

Sumber: Data Hasil Validasi

Berdasarkan tabel 4 tingkat keefektifan media scrapbook berbasis picture and picture berorientasi wawasan kebangsaan yaitu 96\%. Dari hasil tersebut terlihat bahwa dari 20 siswa anak umur 6-8 tahun SD Namira School Probolinggo, ada 18 siswa telah tuntas belajar, sedangkan 2 siswa lain tidak tuntas belajar. Kriteria Ketuntasan Minimal (KKM) individu di kelas tersebut adalah 70. Dari hasil tingkat keefektifan dan KKM individu, pembelajaran di 
anak umur 6-8 tahun SD Namira School Probolinggo pada tema hidup rukun dapat dikatakan efektif. Kriteria kepraktisan media scrapbook berbasis picture and picture berorientasi wawasan kebangsaan masuk ke dalam kategori praktis dan tidak perlu revisi.

Tabel 4 Hasil Analisis Tingkat Kepraktisan dan Keefektifan

\begin{tabular}{|c|c|c|c|}
\hline Aspek yang dinilai & Sasaran & Hasil & Saran dan Komentar \\
\hline Kepraktisan $(P 2)$ & Guru $(P 1)$ & $90 \%$ & $\begin{array}{l}\text { Sebaiknya gambar yang terdapat pada media } \\
\text { pembelajaran juga dicetak (print) agar siswa } \\
\text { dapat mengisi kembali soal yang telah } \\
\text { dipelajari pada media pembelajaran }\end{array}$ \\
\hline Keefektifan $(E)$ & Siswa & $96 \%$ & - \\
\hline
\end{tabular}

Berdasarkan hasil kedua validator ahli dapat disimpulkan media scrapbook berbasis picture and picture berorientasi wawasan kebangsaan memenuhi aspek teoritis maupun praktis sehingga media dapat digunakan dengan baik. Hal ini sejalan dengan (Manurung and Panggabean, 2020) media pembelajaran ini mendapat komentar perbaikan petunjuk dan cover untuk penyempurnaan media scrapbook berbasis picture and picture berorientasi wawasan kebangsaan. Hal ini juga didukung oleh (Khan and Masood, 2015) bahwa media pembelajaran yang mengalami perbaikan menyesuaikan karakteristik siswa dapat meningkatkan hasil belajar.

Media scrapbook bernomor berisi 15 gambar yang berfungsi untuk menjelaskan materi pembelajaran. Gambar-gambar scrapbook diletakkan pada papan sesuai dengan urutan (Veronica, Subekti and Tsalatsa, 2019). Gambar pada media scrapbook yang dimaksud adalah gambar hidup rukun disekolah, gambar tersebut dipilih sesuai dengan materi dan karakteristik siswa sekolah dasar. Kombinasi warna yang porposional pada gambar sesuai dengan materi yaitu adanya beberapa siswa yang berseragam merah putih dengan latar kelas yang berwarna kuning dan didepan kelas yang terlihat bersih dan rapi yang berwarna hijau. Desain ini dapat meningkatkan minat belajar siswa dengan memberikan muatan-muatan wawasan kebangsaan. Hal ini sejalan dengan (Chachil et al., 2015) hasil belajar siswa juga dapat meningkat dikarenakan siswa antusias dalam menerima dalam pembelajaran. Hal ini juga didukung oleh (Moniaga et al., 2019)bahwa anak yang bermasalah seperti lambat belajar dapat diberikan media untuk merangsang minat proses belajarnya.

Buku petunjuk penggunaan media scrapbook berbasis picture and picture berorientasi wawasan kebangsaan adalah buku petunjuk penggunaan media mengkombinasikan media scrapbook dan metode picture and picture serta menambahkan variabel wawasan kebangsaan. Media ini dapat meningkatkan proses dan hasil belajar serta menumbuhkan wawasan kebangsaan pada anak sejak usia dini. Buku petunjuk media ini yang disusun dalam bentuk print out. Tujuan dari disusunnya buku ini adalah sebagai pedoman bagi guru untuk menggunakan media scrapbook berbasis picture and picture berorientasi wawasan kebangsaan dengan lebih mudah. Hal ini sejalan dengan (Rulyansah and Sholihati, 2018) buku petunjuk ini berisi spesifikasi produk,yaitu spesifikasi tentang produk yang dikembangkan yaitu, media scrapbook berbasis picture and picture berorientasi wawasan kebangsaan. Pada lembar berikutnya yaitu story board, merupakan gambaran atau alur cerita dari media scrapbook berbasis picture and picture berorientasi wawasan kebangsaan. Hal ini sejalan dengan (Anggraini, Ambarika and Rai, 2020) buku ini dilengkapi dengan perangkat pembelajaran yaitu silabus, RPP dan lampirannya. Jadi sebelum menggunakan media scrapbook berbasis picture and picture berorientasi wawasan kebangsaan, guru memahami dahulu isi dari buku petunjuk (Cronin et al., 2020). Guru mengenal media scrapbook berbasis picture and picture berorientasi wawasan kebangsaan baru bisa menjelaskannya kepada siswa dan kemudian menggunakan media tersebut sesuai dengan silabus dan RPP yang telah ada dalam buku petunjuk. 


\section{SIMPULAN}

Berdasarkan hasil validator dari aspek kevalidan dan kepraktisan media scrapbook berbasis picture and picture berorientasi wawasan kebangsaan memenuhi aspek valid (tidak perlu revisi) dan praktis (tidak perlu revisi). Hasil validasi guru dan siswa dari aspek kepraktisan dan keefektifan memenuhi aspek praktis dan efektif. Disimpulkan bahwa media scrapbook berbasis picture and picture berorientasi wawasan kebangsaan layak digunakan untuk menjadi solusi dalam pembelajaran sehingga berdampak positif dalam perkembangan kognitif dan motivasi anak usia dini.

\section{UCAPAN TERIMA KASIH}

Terima kasih kepada Kepala Sekolah SD Namira School Probolinggo yang telah memberikan ijin untuk berlangsungnya penelitian dan pengembangan ini, dan kepada guru dan siswa Anak umur 6-8 tahun serta kepada tim jurnal obsesi telah mempublikasikan penelitian ini.

\section{DAFTAR PUSTAKA}

Abtahi, M. S. (2012) 'Interactive Multimedia Learning Object (IMLO) for Dyslexic Children', Procedia - Social and Behavioral Sciences, 47, pp. 1206-1210. https://doi.org/10.1016/j.sbspro.2012.06.801

Anggraini, N. A., Ambarika, R. and Rai, R. P. (2020) 'Effect of providing basic life support for improving skills in first aid on cardiac arrest for student of senior high school in Kediri', Enfermeria Clinica. Elsevier España, S.L.U., 30(2019), pp. 50-54. https:// doi.org/10.1016/j.enfcli.2019.12.037

Atkins, R., Turner, A. J., Chandola, T., \& Sutton, M. (2020) 'Going beyond the mean in examining relationships of adolescent non-cognitive skills with health-related quality of life and biomarkers in later-life.', Economics and Human Biology, 39, p. 100923. https://doi.org/10.1016/j.ehb.2020.100923

Borg, W. R. and Gall, M. . (1983) Education Reseacrh An Introduction (Fourth Edition). New York: Longman Inc.

Chachil, K. et al. (2015) 'Interactive Multimedia-based Mobile Application for Learning Iban Language (I-MMAPS for Learning Iban Language)', Procedia - Social and Behavioral Sciences. Elsevier B.V., 167, pp. 267-273. https://doi.org/10.1016/j.sbspro.2014.12.673

Cronin, L. et al. (2020) 'Life skills development in physical education: A self-determination theory-based investigation across the school term', Psychology of Sport and Exercise. Elsevier, 49(May), p. 101711. https://doi.org/10.1016/j.psychsport.2020.101711

Fauziyah, S. L. et al. (2020) 'Pengembangan Media Pembelajaran Scrapbook Untuk Meningkatkan Motivasi Belajar Pada Materi Vertebrata di Kelas X MA NU Hasyim Asy ' Ari 3 Kudus, Bioduca: Jurnal Pendidikan Biologi, 02(1), pp. 19-29. https://doi.org/10.21580/bioeduca.v2i1.5996

Halim, Abdul ; Wardana, L. A. (2017) 'Implementation of the Value of Mutual Cooperation through Local Wisdom in Petik Laut District Mayangan Probolinggo', Advance in Economics, Business and Managemen Reseacrh, 45(Agustus 2017), pp. 127-131. https://doi.org/10.2991/coema-17.2017.21

Hobri (2010) Metodologi Penelitian Pengembangan. Jember: Pena Salsabila.

Khan, F. M. A. and Masood, M. (2015) 'The Effectiveness of an Interactive Multimedia Courseware with Cooperative Mastery Approach in Enhancing Higher Order Thinking Skills in Learning Cellular Respiration', Procedia - Social and Behavioral Sciences. Elsevier B.V., 176, pp. 977-984. https:// doi.org/10.1016/j.sbspro.2015.01.567

Manurung, S. R. and Panggabean, D. D. (2020) 'Improving students' thinking ability in physics using interactive multimedia based problem solving', Cakrawala Pendidikan, 39(2), pp. 460-470. https:// doi.org/10.21831/cp.v39i2.28205 
Moniaga, J. V. et al. (2019) 'Map-type modelling and analysis of children stunting case data in Indonesia with interactive multimedia method', Procedia Computer Science. Elsevier B.V., 157, pp. 530-536. https:// doi.org/10.1016/j.procs.2019.09.010

Pertiwi, H. (2019) 'Pengaruh Penggunaan Media Scrapbook Beredisi Islami Terhadap Perkembangan Kognitif Anak Usia 5-6 Tahun di TK Aisyiyah 04 Surabaya', PEDAGOGI: Jurnal Anak Usia Dini dan Pendidikan Anak Usia Dini, 5(1), pp. 101-108. https:// doi.org/10.30651/pedagogi.v5i1.3615

Rulyansah, A. and Sholihati, M. (2018) 'Pengembangan Modul Berbasis Kecakapan Hidup pada Pelajaran Matematika Sekolah Dasar', MUST: Journal of Mathematics Education, Science and Technology, 3(2), p. 194. https://doi.org/10.30651/must.v3i2.2088

Rulyansah, A. and Wardana, L. A. (2020) 'Pengembangan Perangkat Pembelajaran Matematika Berbasis Kompetensi 4K Anies Baswedan dan Multiple Intelligences', Jurnal Basicedu, 4(4), pp. 1236-1245. https:// doi.org/10.31004/basicedu.v4i4.539

Rulyansah, A., Wardana, L. A., \& Sari, I. N. (2018) 'Idealisasi Ideologi Pancasila untuk Pencegahan Radikalisme melalui Aktivitas Bela Negara pada PK2MABA Universitas Panca Marga', Jurnal Pendidikan: Teori, Penelitian, Dan Pengembangan, 3(12), pp. 1680-1687. https://doi.org/10.17977/JPTPP.V3I12.13103.

Veronica, I., Subekti, E. E. and Tsalatsa, A. N. (2019) 'Pengembangan Media Pembelajaran Scrapbook pada Pembelajaran Tematik Kelas I SDN Taman Sari 01 Pati', Jurnal Sinektik, 2(1), p. 26. https:// doi.org/10.33061/js.v2i1.2986

Wardana, L. A. and Hasanah, U. (2019) 'Panduan Lingkungan Ruang Kelas Berorientasi Multiple Intelegences di Sekolah Dasar', Jurnal Pendidikan: Teori, Penelitian, \& Pengembangan, 5(4), pp. 447-453. http:// dx.doi.org/10.17977/jptpp.v4i4.12648

Wardana, L.A.; Alawiyah, Y. T. (2021) 'Pengembangan Media Pembelajaran Monopoli Berbasis Tematik Pada Tema 4 (Hidup Bersih Dan Sehat) Kelas II SDN Sumbersuko Kabupaten Probolinggo', Jurnal Pedagogy, 08(01), pp. 23-26. https://doi.org/10.51747/jp.v8i1.700 